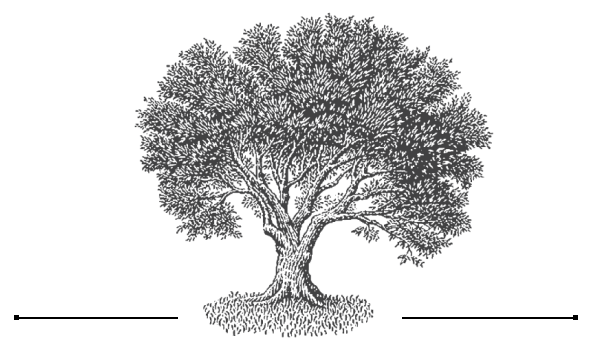

Theory and Practice of Parochial Preaching in the late 18th-century Polish-Lithuanian Commonwealth*

\section{Stanisław Witecki}

Jagiellonian University

Kraków, Poland
Теория и практика приходской проповеди

в Речи Посподитой

в конце XVIII столетия

\author{
Станисдав Витецкий \\ Ягеллонский университет \\ Краков, Польша
}

\title{
Abstract
}

In the last decades of the 18th century, a few Polish dioceses were governed by representatives of the Catholic Enlightenment. Their pastoral activities focused on the reform of the priesthood and, especially, on the duty of preaching. Despite being perceived as members of a single group, their ideas differed to the point of being mutually contradictory. Interpretation of the ideological differences among these bishops is the preliminary aim of the paper. I examined pastoral letters and preacher handbooks written by four of these bishops: Michał Poniatowski, Ignacy Massalski, Wojciech Skarszewski, and Porfiriusz Skarbek-Ważyński. However, my main concern is the social practice of parochial preachers in their dioceses. I was interested in the methodology of sermonizing, the frequency of preaching topics, and the style and content of homilies delivered by clergy. I based my research on pastoral visitations, especially from the Diocese of Płock, providing information about the printed collections of sermons used by parochial clergy as well as the texts they wrote. The main conclusions are as follows: the clergy adopted to some extent only those reforms which were adjusted to their parochial needs and were supported by administrative pressure. Regardless of theoretical programs,

* The research is funded by the Polish Ministry of Science and Higher Education (2012-2015) under the Diamond Grant program (project no. DI2012018742). 
preaching in the Commonwealth was changing in the direction of "Enlightened Tridentine Catholicism." This means that the clergy accepted an enlightened style and language and a focus on morality, but not models of social and natural worlds. However, by rejecting the latter, they avoided enhancing the process of division between popular and elite.

Keywords

Catholicism, parochial preaching, Enlightenment, book collections, models of the social and natural world

\section{Резюме}

В последние десятилетия XVIII века несколько польских епархий находились под управлением представителей катодического священства. Их пастырская деятельность сконцентрировалась на реформе духовенства, в частности, на распространении проповедничества. Несмотря на то, что эти люди воспринимались как члены одной группы, их идеи могли радикально раздичаться. Я исследовал пастырские письма и “Учебник для проповедника", написанные четырьмя епископами: Михалом Понятовским, Игнатием Массальским, Войцехом Скаршевским и Порфирием Скарбек-Важинским. Однако моей главной задачей было изучение социальной практики приходских священников в их епархиях. Меня интересовала их методика проповедования, частота тем, стиль и содержание проповедей, произнесенных духовенством. Мое исследование опирается на описание пасторских визитов (в первую очередь в Полоцкой епархии), в которых сохраняется информация об использованных колиекциях проповедей, а также на тексты, написанные приходскими священниками. В результате исследования можно сделать вывод, что священники тодько частично усвоиди результаты реформ, приспособленных для приходских нужд и поддержанных административными средствами. Несмотря на теоретические программы, проповедь в Речи Посполитой менялась в направлении “Катодического триденского Просвещения". Это значит, что священники приняли стиль и язык Просвещения и сосредоточились на нравоучении, а не на моделях социальных и естественных миров. Однако, отказываясь от них, они избежали распространения разделения культуры на элитарную и популярную.

\section{Ключевые слова}

катодицизм, приходское проповедование, Просвещение, библиотеки, модели социального и природного мира

\section{Preface}

Parochial preaching in the Polish-Lithuanian Commonwealth in the late 17th century was a well-established social practice. The obligation to deliver a sermon every holiday and Sunday was imposed by bishops, especially after the Council of Trent [ZwiązeK 1977: 26-27]. The clergy might have prepared their own text based on the Bible, on works of the Church Fathers, or on catechisms, but apparently most of them used printed collections of sermons, 
which constituted the main body of parish book collections at least from the 16th century [WYCZAWSKI 1953].

Clergy who were willing to buy a printed collection of homilies had a variety of texts and authors to choose from. Since seminaries and monastic colleges taught how to deliver homilies, every priest was at least supposed to have some preaching skills [KASABUŁA 1996; GRZYBOWSKI 1973]. The most talented were mainly monks who held the official position of a preacher in the monastic, collegiate, and cathedral churches. They delivered sermons not only on a daily basis, but also during public political events, and therefore could easily gain popularity among the nobility and patriciate. The existence of a regular group of listeners was a good reason for printing entire collections of sermons, and publication frequently occurred with the consent of or active promotion by bishops [ZWIĄZEK 1997-1998; SZCZUROWSKI 2004].

Homilies were obligatory for parochial clergy but their usage also corresponded to social needs. Those needs, however, changed over time, and so did the style, topics, and functions of written sermons [PELCZAR 1886; BRzozowsKI 1975]. At the end of the 16th and the beginning of the 17th centuries, sermons served as religious polemic against Protestantism, and were written in the characteristically persuasive style of Renaissance rhetoric [ZWIĄZEK 1977: 19971998]. In the late 17th century, they dealt with theological nuances, frequently promoting Marian and Christ-centered piety, and were delivered in the conceptual, emotional and ornate baroque style [PAZERA 2000; PANUŚ 2001; WoLAŃSKI 2012]. At the beginning of the 18th century, the style of sermons did not change much but the main purpose of the Church was to educate the people, and to do so, the focus was on teaching [WiśLICZ 2005]. Finally, from the mid-18th century, sermons abandoned unnecessary ornaments, examples, and digressions under the pressure of monastic school reforms, and they changed their argumentative tactics in the face of the need to refute secularist ideas [PAZERA 2000].

The present article is concerned with this last period, referred to as the "enlightened age" both by contemporary writers and modern scholars [BuTTERWICK 2005]. However, enlightenment was conceived in a multitude of ways, sometimes with elements contradicting one another. Historians try to organize this chaos of ideas somehow by using such labels as Radical Enlightenment, Catholic Enlightenment, Enlightened Catholicism, and, finally, the CounterEnlightenment [Butterwick 2014]. The characteristic trait of the Polish-Lithuanian Commonwealth was that clergy could be found in all of these groups, and also that the phenomenon of Radical Enlightenment scarcely existed. Despite vivid differences, all shades of Enlightenment thought had common ground: an awareness of the changes that were occurring and an active approach toward addressing them. This notion applies to sermonizing as well [BUTTERWICK 2008; ŚLUSARSKA 2010; SZCZUROWSKI 2014]. 
In the late 18th century there were a few bishops in the Polish-Lithuanian Commonwealth who were trying to influence the methods and topics of parochial preaching [ŚLUSARSKA 1998; SZCZUROWSKI 2011]. Since they had the power and tools to impose their ideas, the first aim of the present article is to interpret their various sermonizing programs. The second aim is not so much to check their effectiveness but rather to investigate the social practice of parochial preaching independently. Both theory and practice might be divided into methodology and ideology. I pose the following set of questions in order to address the first problem. What kind of knowledge was demanded and possessed by a parish preacher? How were they supposed to prepare to give sermons and how, in fact, did they do so? What techniques of language, style, and performance did they rely on? What was the suggested aim of delivering sermons and what were the true aims?

The second problem invokes questions about views on natural, social, moral, and dogmatic issues promoted both by bishops and by parish clergy. In answering all these questions, I attempt to solve broader concerns of cultural history. Did the parochial preaching practice support or restrict the process of division between elite and popular culture, and did the sermon help in promoting modern concepts of nature, reason, freedom, and citizenship?

\section{Methodology}

The analysis of books written by contemporary writers can be misleading because changes in their content did not directly translate into the style and topics of parochial preaching. Homilies had to be bought, read, and adopted in the first place [ZwIĄZEK 1997-1998]. Since writers promoting new cultural trends competed with those faithful to a variety of ever-accumulating traditions, parsons and vicars had to choose from these available options. Also, it is equally important to note that sermon collections of the best-known preachers from previous ages were still available in bookshops [IMAŃSKA 2000; RUDNICKA 1972].

Thus, it is necessary to begin by checking which books parsons and vicars owned, read, and employed in the process of preparing their own sermons. Only the most frequently used homilies should be taken into account. This information can be found in the records of the canon visitations. Most of them included indexes of parish book collections, which show only the accumulated reading tradition to the point of the decease of a former parson [LITAK 1962]. However, the visitations of the Diocese of Płock conveyed by the order of Bishop Michał Poniatowski in 1775-1776 and 1781 contained additional indexes of private, recently bought books, and divided all of them according to the criterion of function. Additionally, priests themselves declared the most important topics of their sermons [MDDZP, 1-15]. I have categorized this information 
according to the divisions taken from catechisms [WAŻYŃSKI 1792; WUJKOWSKI 1733], but also according to the detailed instructions about preaching topics provided in Bishop Poniatowski's pastoral letter [PONIATOWSKI 1785, 1: 406-442]. I have counted the number of priests declaring certain themes in order to compare practice and theory. Furthermore, the book drawn up by the diocese, made up of printed homilies delivered by parish clergy, has survived. I have analyzed all of these sources separately, but in the present article I present them collectively as parish clergy discourse in general, not singling out any particular authors.

The Diocese of Płock has been the main focus of the investigation of preaching practice because other dioceses did not provide such information. This diocese was also crucial to the research into theory, since Bishop Michat Jerzy Poniatowski was one of the leading reformers [ZIELIŃSKA 1977]. The choice of this diocese seems to be self-explanatory, although it is not sufficient to draw conclusions about preaching theory throughout the entire Commonwealth. Investigating all dioceses, however, is not possible, so it was necessary to identify other specific dioceses to consider for research.

I had no doubts that the Diocese of Vilnius would be my choice, since it was the biggest and most important in the Grand Duchy of Lithuania. It was also governed by Ignacy Massalski, a bishop who revealed his opinions about sermonizing and who supported preachers, and whose ideas were undoubtedly enlightened but in a completely different manner from those of Michał Poniatowski [KASABUŁA 1998; ŚLUSARSKA 2010; GRZYBOWSKI 1983].

It was also necessary to investigate one of the dioceses of the Archdiocese of Lwów. I have chosen the Roman Catholic Diocese of Chełm and the Greek Catholic Diocese of Chełm, which were part of the Kiev Greek Catholic Archdiocese, because comparison between two traditions seemed to be valuable. Their territories overlapped almost entirely and were situated in the PolishRuthenian ethnic borderland [DĘBIŃsKI 1914; BoBRYK 2005; GIL 2005; KUMOR-MIELNIK 2010]. Such comparison was not a sufficient cause to choose them, however, since there were other similar pairs of dioceses. The main reasons for their selection were, once again, the bishops who ruled them at the end of the 18th century. In the Roman Catholic diocese, the leader was Wojciech Skarszewski, one of the most active polemicists and reformers but also a conservative whose ideas exemplify the thin line between Catholic Enlightenment and Counter-Enlightenment [ButTERWICK 2012: 626-630; 2008: 208]. In the Greek Catholic counterpart, it was Porfiriusz Skarbek Ważyński, the first bishop who asked the clergy about their books [ŁAPIŃSKI 1985].

It is necessary to indicate briefly that the analysis of the most frequently used books requires a long and difficult process of identification based on rough descriptions by visitors [SZADY 2008], constructing a large database, 
and employing statistical analysis. Nuances of this process were explained elsewhere [WITECKI N.D.], and data are presented on my webpage: http:// ksiegozbioryparafialne.omnino.com.pl/.

\section{Enlightenment by Superiority of Knowledge}

The theory of preaching was imposed on the parish clergy of the Diocese of Płock in a pastoral letter that was more than two hundred pages long. It was designed as the main regulation, to be used in place of the regulations previously supplied by the diocesan synods. It was signed by Michał Poniatowski, but in all likelihood it was prepared by a group of collaborators headed by auditor Krzysztof Żurawski [GRZYBOWSKI 1983: 35-42]. In the context of this article, authorship is less important than the means of implementation, which translated to its effectiveness.

The pastoral letter was published at the beginning of the pontificate on 20 August 1775, and was sent to all parsons as a binding set of rules [PONIATOWSKI 1785, 1: 391-589]. Furthermore, deans were required to read it loudly at the obligatory deanery congregations, organized twice a year. The implementation of the new law was tested during the visitation announced on $8 \mathrm{March}$ 1775 [IBID.: 292-337], and conducted between 1775 and 1781. Violations were to be punished in the form of fines and mandatory re-education. So, the program of preaching applied in the Diocese of Płock was more of an enforced law than a pure theory. Subsequent analysis is based on the views of this letter presented in many places, and I have omitted repeating references to the same source [IBID.: 406-442].

The program was based on a clear hierarchy of values. The most important was salvation, and the only duty of a priest was to do whatever was possible in order to bring the faithful closer to God. In accordance with Catholic dogma, salvation depended on faith and morality; the latter, however, was given overwhelming preponderance in the program. Moral behavior was, in turn, dependent mainly upon the knowledge of good and bad, whereas sins were caused by ignorance. Thus, the duty of parish clergy was, in fact, to teach good manners. However, the authors of the program believed that education was based on personal example, and particularly on the moral and intellectual superiority of the priests. As a consequence of the belief in a direct relationship between knowledge and morality, the program very briefly dealt with the methodology of preaching.

Sermons had to be, above all, well structured according to the appropriate rules and devoid of any digression or unnecessary information. Sermonizing had to be focused on promoting virtues, and if condemning sins was necessary, it had to be done gently and never individually. Since the art of preaching was difficult, authors of the program, although reluctantly, agreed to the practice 
of reading printed homilies from the pulpit. They found it less harmful than speaking "anything which comes to the preacher's mind" [PONIATOWSKi 1785: 416], however, they decided to supplement the pastoral letter with a detailed list of recommended books in order to make sure that the priest would read acceptable texts. They mentioned eight renowned Polish and foreign preachers from the late 16th and early 17th centuries, and seven contemporary authors whose works, without exception, are nowadays considered an integral part of Enlightened Catholicism. The recommended sermons, both old and new alike, had in common the use of language without Latin inclusions, well-organized structure, and simple, though persuasive, rhetoric. Most of them focused predominantly on moral issues, even if they derived them from dogmas or sacred stories [WITECKI 2017].

Authors of the pastoral letter paid much more attention to the topics of sermons. They can be divided into three classes of priority, according to the amount of text dedicated to them and the length of the descriptions of violations related to the topic. The most important theme of the sermons was supposed to be the problem of intemperate alcohol consumption, a social plague fatally affecting other behavior and depriving humans of dignity. Equally important was the promotion of the virtue of love, derived from the great commandment, but interpreted with the greatest stress on love for people and works of mercy. The beliefs necessary to salvation and, especially, the Four Last Things, were also classified among the most important issues to be addressed in sermons.

The second class of priority involved a restrictively treated sexual morality. Clergy would condemn not only adultery, but even conversation with and presence in the proximity of suspicious people. Apart from that, the authors of the pastoral letter obliged parsons and vicars to preach about a wide range of socio-economic values. First of all, they had to promote the idea of the equality of people in the eyes of God, and, consequently, the duty of inter-estate respect. Second, they were to denounce disrespect for serfs as well as frauds and intrigue, simultaneously promoting modesty. It is clear that, as a whole, such socio-economic preaching was addressed to the nobility, and its aim was to mitigate the harshness of the feudal system. On the other hand, the obligation to respect estate responsibilities, addressed mostly to the peasantry, was one of the least important topics. These topics were supplemented by such traditional religious values as piety and asceticism, represented by contempt of the world and mortification of the senses. Finally, among these topics were situated laziness, wrath, and greed, the foundation of the Seven Deadly Sins.

The catalogue may be supplemented by the most important topics discussed by the recommended authors, such as Samuel Wysocki, Kasper Baslam, and Wawrzyniec Rydzewski. The dignity and obligation of work, the refinement of manners, the obligation to work toward political community, and, most 
of all, the rehabilitation of reason as a source of both knowledge and faith, are the ideas referred to as enlightened [ZAKRZEWSKI 1986]. The last idea-the rehabilitation of reason as a source of both knowledge and faith-was also a constant theme of the pastoral letter as a whole. Authors fought against magic and witchcraft not as a sin but as a superstition, and they promoted independent studies of the Bible by the clergy. Therefore, the most important feature of the theory of preaching in the Diocese of Płock was its intellectualism, and the program can be called enlightened through its moral and knowledge superiority.

\section{Enlightenment by Simplicity and Utility}

In the Diocese of Vilnius, Bishop Ignacy Massalski did not write a single pastoral letter that was meant to serve as a set of mandatory rules. His views about preaching did not take the form of law and their implementation was not tested. However, he did present his opinions in many ways [KASABuŁa 1998]. First, during the jubilee in 1776 he issued a long and detailed list of topics that had to be preached [MASSALSKI 1776]; he supported some extraordinary preachers by printing their works [SzCZUROWSKI 2004; ŚLUSARSKA 2010]; and, finally, in 1793 an anonymous parenetic book titled Kapłan stuga boży y pasterz dusz czyli list xiędza plebana do xiędza brata swego zamykaiacy w krótkim zebraniu obowiazki kaptańskie i pasterza dusz, which was about the ideal priest, was printed, presenting a full program of sermonizing, part of which was written directly by the bishop [KAPŁAN SŁUGA BOŻY 1793]. Further analysis is based mainly on the latter source and the instruction for the jubilee.

Differences between programs imposed in Lithuania and Mazovia began with the hierarchy of values. For Ignacy Massalski, salvation was only one of the preaching aims. Equally important was the quality of life on earth, which sermons had to enhance by teaching not only morality but also practical knowledge essential for economic well-being and health. This general transition toward earthly utility had deep consequences in the promoted values and topics of sermons.

Since redemption was not the only aim of preaching, a set of values directly derived from theology were enriched with concepts of happiness, helpfulness, and peacefulness. The traditional ideal of piety was reinterpreted as good manners, fairness, and utility. Most of these values were related to the idea of effective collaboration among people and were preached in the context of social institutions. One of these institutions was family, considered widely as a set of relationships between spouses, between parents and children, and between householder and farmhand. Another institution was the village, understood as a union between a landlord and serfs. The last one was the state, which was understood mostly as a set of relationships between a monarch and the nobility, who are named, significantly, not as subjects but as citizens. Although the 
term "patriotism" was not used, preachers were nevertheless expected to promote this value. As a whole, these values gave rise to concrete responsibilities, such as mutual respect, hard work, the repair of roads and bridges, and prayer for the fatherland. Of course, apart from these merits, all traditional Catholic virtues and sins, enumerated in every handbook of moral theology, were still to be preached.

The most outstanding characteristic of Ignacy Massalski's theory was, however, the obligation to use sermons as a tool to transmit information from beyond the realm of morality. As the first chairman of the National Education Commission, he is best known for promoting the establishment of parish schools. He demanded that preachers should justify the need for educating both boys and girls in order to combat superstition and train more effective laborers. Promotion of education should not be misread as intellectualism, since the bishop of Vilnius simultaneously discouraged clergy from any reasoning about dogmas or presenting opposing views that were held by other Christian denominations. Beliefs had to be accepted only by faith, and preaching these beliefs was to be as short as possible. Much more important was to promote the bishop's physiocratic ideals of reforming agriculture. He required the priest to deliver sermons dedicated to the cultivation of gardens, handcraft, and trade, in addition to the use of proper tools, such as ploughs and harrows. From the desire to improve farming conditions derived his notions about inter-estate respect and responsibilities. All of these topics were preached extensively by Wilhelm Kaliński and Franciszek Karpowicz, writers promoted by the bishop of Vilnius.

These outstandingly concrete and utilitarian ideas had to be delivered in a manner that was calibrated to the listener's capabilities. Since it was obvious that most of the preached values were addressed to the peasant, the main feature of sermons was supposed to be simplicity. It was clearly stated that parish clergy were not allowed to imitate the style typical of municipal and public preachers, but instead to make sermons which resembled the peasants' style, vocabulary, and way of thinking. The authors of Kaptan stuga boży even listed Latin words that were to be avoided, and suggested that even biblical citations should be translated into Polish. However, citations, digressions, and comparisons in general were condemned, and perceived as boring to the listeners. For the same reasons, sermonizing had to be loud, well-pronounced, and varied in timbre. Since such vocalization was impossible while reading, the practice was forbidden; if reading was unavoidable, the priest was not expected to read entire sermons, but rather short passages from simple, ascetic books. To ensure the attention of the faithful, sermons were supposed to be delivered in the morning and to be short. It can be concluded that Ignacy Massalski did not believe in the direct power of words, and found methodology crucial for 
effective preaching. And this was the justification for requiring preachers to be gentle in their approach, because frank assessments of flaws might have discouraged listeners. It is worth noting, however, that all this simplicity must not have been merely justification for lack of skills and knowledge. On the contrary, as the folk style was not natural for the preachers, they had to prepare themselves even harder in order to realize these goals.

\section{Counter-Enlightenment Reform}

Wojciech Skarszewski became the bishop of the newly organized dioceses of Chełm and Lublin at the end of the Four-Year Sejm. He was a well-known journalist who actively fought against secularist projects of the parliament, defending clergy but also criticizing their shortcomings and accepting the need for some reform. His project is a good example of a Counter-Enlightenment set of conservative, although not reactionary, values [BUTTERWICK 2008: 208]. Soon after his consecration, he issued the pastoral letter serving as a new mandatory set of rules [SKARSZEWSKI 1792]. It was sent to all parsons, and deans were obliged to read it during obligatory congregations. This action was similar to that taken by Michał Poniatowski, and it is possible that the pastoral letter was designed as a form of polemic. The analysis below is based on this pastoral letter.

Skarszewski accepted the idea that the most important topic of sermons had to be morality. This notion was common to all of the bishops described so far, and can be found as a general trend in the theory of preaching of the age. However, Skarszewski not only prioritized moral issues, as Massalski did, and he not only practically restricted preaching about these topics, as Poniatowski did, but he also literally forbade clergy to preach about any nonreligious topics. He strongly believed that every estate had its own responsibilities, and he did not agree with the notion that a priest had to engage in economic or hygienic education.

His precise views about moral teachings were also exceptional, since he limited them to condemning sins according to the Ten Commandments, and he described the most commonly committed sins: murder, adultery, theft, perjury, and one social vice that does not appear in the Decalogue-intemperance in alcohol consumption. Focusing on sins and on virtues distinguished his program from the others described above. He did not promote the vision of God as more just than merciful. Although, in general, he did not encourage preaching about social issues, he did mention estate responsibilities. However, as opposed to Massalski and Poniatowski, he focused only on the subjects' duty of subordination, omitting the necessity of the nobility's respect toward the peasants.

Skarszewski had precisely the same opinion as Massalski, and forbade explanations of dogmas which, he believed, were to be based on faith alone. 
His opinion about the role of reason was, however, much more conservative. He did speak against witchcraft as a superstition, and even condemned practices which did not derive from faith but were not contrary to it. However, in the same passage he suggested that the Church had to tolerate some vices of belief in order to avoid loss of faith. He accepted the clergy's responsibility to organize parish schools, yet he did not mention this in his preaching theory, and generally perceived this obligation as useful for the Church because it served as a preliminary training for future priests and church servants.

The bishop of Chełm and Lublin did not pay much attention to preaching methodology. Like all of the previously described hierarchs, he condemned the use of misleading examples, stories, and comparisons of saints. In the program of the seminar, he also discouraged future preachers from using emotional gesticulation and vocalization. Delivering sermons was to be made in a serious manner. He recommended basing sermons on the Bible and Church Fathers and, like Poniatowski, he provided a list of recommended books. It was, however, a completely different literary canon. There were no contemporary authors, and the only preachers were Piotr Skarga and Wojciech Tylkowski. Apart from that, he suggested reading Bible commentary and ascetic meditations. In general, he fought against the obvious weaknesses in preaching that he observed, and he turned to the past, not to contemporary examples, for inspiration in order to correct these faults.

\section{Greek Catholic "Tridentinization"}

Porfiriusz Skarbek-Ważyński became an eparch of the Greek Catholic Diocese of Chełm in 1790, and, despite his strong involvement in the Four-Year Sejm and then in the Kościuszko Uprising, he was engaged in church reforms [ŁAPIŃSKI 1985]. From 1791 on, he organized synods every year, and during these gatherings he personally met with priests and gave them orders, which, of course, were obligatory [Likowski 1902]. In 1793 he organized a deanery visitation, intended to control implementation of his program.

According to canon visitations prior to the last decade of the 18th century, there were no parish book collections apart from liturgical books [SYGowSKI 2000]. Seemingly, there was no tradition of sermonizing. However, Bishop Skarbek-Ważyński was born as a Roman Catholic, and during his political career was a supporter of the most progressive movements, and I have presumed that his program would try to bring Greek Catholic culture closer to the Roman patterns. And in many ways, it did.

Rules issued during the synod were based on those written during the provincial synod in Zamość, in 1720, which were intended to adjust the Uniate Church's practices to those established at the Council of Trent. Bishop Skarbek-Ważyński focused especially on teaching basic Catholic beliefs, which 
apparently had been neglected. At first, he wrote and printed catechisms, and then he ordered every priest to buy them to use as a handbook in the newly organized Brotherhoods of Christian Knowledge [WAŻYŃSKI 1792]. He also insisted on the obligation to study moral theology. However, he did not say a word about the necessity of delivering sermons.

\section{Shades of Enlightenment-The Practice of Preaching}

In the Diocese of Płock, the preaching methodology happened to be much more similar to the theory of Bishop Massalski than to that of Bishop Poniatowski. ${ }^{2}$ Priests declared that they had simplified their argumentation to make it understandable for the group of the faithful, which consisted of peasants, citizens of small towns, and the nobility. For the same reason, they used language and styles resembling those of their listeners. Interestingly, they justified their methodology practically but also named it as contemporary, being fully aware that addressing sermons to the folk and using modern classicistic rhetoric taught in reformed monastic schools were approaches compatible with one another. This style was also characteristic of the books most frequently used to prepare the sermons; these books were, without exception, written by contemporary authors recommended in the pastoral letter. Thus, the reform was at least partially successful.

It was not, however, fully effective because the clergy did not adopt all the recommended books, but made a firm and well-directed selection of the most practical genres: moral theology and sermons. Among the latter, they chose predominantly the sermons written by three authors: Samuel Wysocki, Kasper Balsam, and Wawrzyniec Rydzewski. The most popular was Samuel Wysocki, who was admittedly the most traditional preacher, and whose modernity was visible only in language. When it came to the topics he chose, he always interpreted biblical excerpts in terms of moral teachings, which, of course, was consistent with the views of all the bishops described above. He promoted solemnity during masses and fought against many behaviors traditionally accepted among the folk, which was similar to Bishop Poniatowski's attempts to restrict the popular para-liturgy [WYSOCKI 1768; IDEM 1760; BĄK 2002]. The sermons of Wawrzyniec Rydzewski were stylistically similar [RYDZEWSKI 1768B; IDEM 1768A].

On the other hand, the second most popular author was Kasper Balsam, who was a preacher of especially enlightened views, in addition to his rhetoric, which was exemplary for its classicism [PAZERA 2000:39-48; GRZEBIEŃ 1981]. He preached extensively about the estate responsibilities of the nobility with

2 All information about the content of book collections and declarations about the topics and style of preaching in the Diocese of Płock derives from the following extensive sources: [MDZP, 1-15; $A V$ 288; $A V$ 307]. 
respect to the peasants, and about the duties of good citizens, all of which resembled Massalski's program. The most striking elements of his approach were his views about the role of reason. He thought that reason was equally important as faith, and that they were allies in establishing the unshakable certainty of Catholic morality [BALSAM 1761]. This belief in reason resembled only the program of the bishop of Płock.

The style and ideology of books used in the Diocese of Płock resembled the enlightened Catholic values. It seems that parish clergy at least knew and accepted them. However, it is important to note that the most extensively used book was not a sermon but the catechism Chleb duchowny. ., written by Jan WUjKowsKi [1733]. This shows that the practice of sermonizing was interrupted at the beginning of the 18th century, and that catechism teaching was still dominant. The catechism presented a style and content that contradicted the views presented in Michał Poniatowski's letter. What is more, the parochial clergy's own declaration of preaching topics was much more conservative and less compatible with the reform program. The most noticeable aspect was the imbalance between preaching against sins, promoting values, and teaching beliefs-the first one was twice as frequent as the other two. This was not consistent with Poniatowski's and Massalski's ideas of transmitting positive examples.

In terms of condemned sins, those from the Decalogue and the Church Commandments dominated. The former occupied a secondary place in the program of Michał Poniatowski, the latter were completely absent. The difference is very significant, since the parish clergy was vividly interested in the participation in the sacraments. Attendance at masses was a precondition of any preaching strategy, and it was essential. However, priests also paid much attention to another sacrament, which showed their more ritualistic attitude towards religion; this was also connected with the iura stolae charges, constituting a large portion of their earnings. Parochial clergy preached a lot about the Seven Deadly Sins, not only about laziness, wrath, and greed. On the other hand, the condemnation of heavy alcohol consumption was relatively rare, and economic misdeeds typical of nobility were completely absent.

The latter was especially striking if preached virtues are taken into consideration. The bishop and his collaborators demanded sermons about modesty, and only two priests delivered sermons about the corresponding vices of pride and luxury. The pastoral letter required the promotion of the idea of the equality of estates in the eyes of God, and there was not even one priest who preached on this topic. On the other hand, clergy often preached about the virtues of dutifulness, patience, humility, and submission, which had the lowest priority in official guidelines. Clergy also sporadically mentioned the need for a fear of God, which was against the vision of a subtle God of mercy. Apart from these significant differences, there were also some similarities. Priests paid as much 
attention to the virtue of love as the bishop and his collaborators did, however, they emphasized the love of God more than the love of the people. Moreover, they sometimes enlisted the love of God as the Great Commandment and sometimes as Theological Virtues, which means that they also preached about faith and hope. The bishop and his subordinates also had more or less similar attitudes to sexual morality, treating it as of mediocre importance.

When it comes to preached beliefs, there are also more similarities to than differences from the blueprint provided in the pastoral letter. Vaguely described "beliefs necessary for salvation" were given the highest priority in the pastoral letter and were often preached by parish clergy. This characterization accounted for the most important dogmas described in all catechisms and moral theology manuals. Among the most important were the Four Last Things, which was also one of the most frequently preached topics. In this context, it is necessary to emphasize again that sacraments were the most frequent theme of the homilies given by the greatest number of priests. This does not mean that Bishop Poniatowski did not care about the rites. He certainly did, but was more interested in the performances of the priests than in the participation by the faithful.

The themes generally selected for preaching showed much greater differences between theory and practice than could be concluded on the basis of an analysis of the books read by the clergy. The list of books that were read and the declared themes of sermons are the only sources that give socially representative data, however they do not show nuances of the content of the sermons. Thus, reading the homilies delivered by parish clergy and monks from the Diocese of Płock was valuable [KAZANIA NIEKTóRE 1785]. It is necessary to remember that sermons were printed with the consent of the bishop and his administration, so they could not include any completely unacceptable ideas. Any differences from the official guide are particularly significant because homilies were written with the full awareness of the editors' views. Further analysis is based on these sermons as a whole, without taking into account all of the differences among authors.

On the surface, their content was consistent with the views of all bishopric guidelines, since morality was a topic considered by almost all of them. However, the clergy much more frequently chose condemnation of sins rather than promotion of values. Among the latter there were homilies about works of mercy and about establishing and maintaining a brotherhood of mercy. Sermons addressing the issue of sins were about heavy alcohol consumption, misdeeds related to money and ownership, as well as about slander and insincerity, which were interpreted as vices obstructing the cooperation among people. This stress on practical morality based on actively helping one another and promoting health was consistent with the views presented in the pastoral 
letter. Apart from these subjects, preachers talked about topics not mentioned in official guidelines, although not prohibited. The most interesting are those against duels and about the duties of doctors, since they were addressed to the nobility and patriciate and they revealed traits not visible in the declaration placed in the visitation protocols.

Although topics of sermons were more or less consistent with the views presented in pastoral letters, clergy contradicted their supervisors at the much deeper level of metaphysical presuppositions. Generally speaking, they provided a model of the natural world dependent only on God. Every social or natural fact, including climate-related accidents, was supposed to occur as the will of God and was interpreted as good in and of itself or as a punishment. This interpretation was contrary to two of Bishop Poniatowski's ideas, which were concerned with the installation of lightning rods and the explanation of storm damage in terms of natural causes [PONIATOWSKI 1785, 4: 183-187]; it was also contrary to Bishop Massalski, who gave scientifically informed advice to fight scarcity and plagues [MASSALSKI 1771; IDEM 1787].

In this deterministic view, the only exception was human behavior, which, on the contrary, was completely free, and therefore people bore full responsibility for their deeds. Where there was sin, there was punishment, and not only given at the final judgment but also during one's earthly life. There were no excuses and no attenuating circumstances, and thus no promotion of changes to the social rules. The social hierarchy was even more relevant in the context of morality. Superiors, such as the nobility or householders, had to control the behavior of subjects, farmhands, and children. Since they were responsible for their salvation, they were obliged to impose punishment. On the other hand, the duty of the subordinates was, first and foremost, to listen to their superiors, even if their requests were not morally correct. So, the individual responsibility in the face of God was weakened by the demands of the coherence of the feudal system.

At the same time, moral behavior was possible only with the accompaniment of faith, and without it, even apparently good action was morally invalid. Thus, faith was the greatest value and it was autonomous, threatened primarily by reason, which was regarded not as an ally but as an enemy. In consequence, preachers discouraged people from thinking independently and even from reading the Bible. This approach was opposite to the views of Kasper Balsam. It may also be significant that there were no sermons against superstition but there was one about the sacrilegious usage of the body and blood of Christ. Since the dogmas were based on faith, and sins were only the fault of the sinner, preachers denied any responsibility for faithful morality, and defended the idea that their abilities and the style of their sermons was irrelevant. This was, of course, completely opposite to Bishop Poniatowski's views, and 
especially to Massalski's. Nevertheless, the clergy insisted on people's obligation to attend mass, listen to sermons, and learn the catechisms, which of course was not against their guidelines.

In the Diocese of Vilnius, clergy did not describe their preaching performance. Book collections are the only, albeit imperfect, source. ${ }^{3}$ They show a vivid tradition of preaching from the late 16th century up to the times of $\mathrm{Bi}$ shop Massalski, with all phases described above, in the introduction. However, with one important exception, there was no time when catechisms substituted for sermons, and authors from the beginning of the 18th century were very popular. The newest visitations demonstrate also the first sign of a change in the direction promoted by the bishop. There were several books by a supporter of physiocracy, Michał Karpowicz, and by a promoter of rhetorical simplicity, Wawrzyniec Rydzewski.

In the Roman Catholic Diocese of Chełm, clergy also did not describe their preaching performance. Most of the information about visitations comes from the 1770s, so it shows collections of books used at the beginning of this century. ${ }^{4}$ They consist mostly of sermons written before the end of the 17th century, and indicate the strength of preaching practice in the golden age of Polish homilies. Apart from that, they consist of catechisms, which indicate the substitution of homilies with basic teachings. Nevertheless, the newest visitation shows a couple of books by Samuel Wysocki, so even in this diocese the practice of preaching was revived in the manner of classicistic rhetoric.

In the Greek Catholic Diocese of Chełm, during the term of Bishop Porfiriusz Skarbek-Ważyński, clergy for the first time revealed the content of parochial book collections. ${ }^{5}$ They consisted of moral theology, mostly published in the previous few decades, ascetic books, and Skarbek-Ważyński's own catechisms. The book culture of Uniate priests thus became more similar to the Roman model, but sermonizing was not part of this process. Differences between the two denominations were still striking after over two hundred years of institutional and dogmatic union and the parallel processes of the Latinization of architecture and the Polonization of the clergy.

3 Information about book collections in the Diocese of Vilnius derives from the following sources: FHL, 6; FHL, 7; FHL, 8; FHL, 9; F.694.1.3381; F.694.1.3417; F.694.1.3437; F.694.1.3440; F.694.1.3459; F.694.1.3461; F.694.1.3477; F.694.1.3478; F.694.1.3485; F.694.1.3487; F.694.1.3489; F.694.1.3492; F.694.1.3494; F.694.1.3499; F.694.1.3500; F.694.1.3506; F.694.1.3512; F.694.1.3517; F.694.1.3562; F57-B53-175; F57-B53-271; F57-B53-308; F57-B53-460; F57-B53-582; F57-B53-858; F57-B53-947; F57-B53-990; F57-B53-1226.

4 Information about book collections in the Roman Catholic Diocese of Chełm derives from the following sources: Rep 60A, 161; Rep 60A, 163; Rep 60A, 164; Rep 60A, 178.

5 All information about book collections in the Greek Catholic Diocese of Chełm derives from the following sources: 35/95/0/5/114, 35/95/0/5/119, 35/95/0/5/120, 35/95/0/5/122, 35/95/0/5/124, 35/95/0/5/127, 35/95/0/5/133, 35/95/0/5/134, $35 / 95 / 0 / 5 / 135$, and $35 / 95 / 0 / 5 / 136$. 


\section{Conclusion}

In the Greek Catholic Diocese of Chełm, Bishop Porfiriusz Skarbek-Ważyński did not propose any theory of sermonizing, and there is no evidence of any such practice. The preaching theory of the Roman Catholic bishops described here can be interpreted through a variety of Enlightenment concepts. Bishop Massalski was closest to the ideas of Catholic Enlightenment. His stress on the nonreligious functions of sermons-especially agricultural efficiency, mitigating the harshness of the feudal system, and stressing patriotic duties-was consistent with the cultural trends of general state and societal transformation, which happened to be introduced by Catholics. The program introduced in the pastoral letter signed by Bishop Poniatowski and his collaborators could be interpreted as Enlightened Catholicism. Imposing only the religious function of sermons but demanding clarity of style, wide erudition, nontraditional ethical values, and the rehabilitation of reason were in line with the cultural trends that reformed the drawbacks of the baroque style and of popular beliefs within the general frame of Catholic theology. Finally, the late program of Bishop Wojciech Skarszewski can be placed somewhere between Enlightened Tridentine Catholicism and Counter-Enlightenment. He was willing to reform the faults of parish preaching caused by individual vanity and the weaknesses of baroque style, but did not intend to change the topics of sermonizing in any way. He actively rejected the idea of any nonreligious duties of the clergy. In this context, it is important to stress that, at some level, all the bishops discussed here shared some of the ideas of Counter-Enlightenment. They actively and openly refuted freethinking, deism, and atheism.

Regardless of the differences in programs in all Latin dioceses, the preaching practice was changing in the direction of Enlightened Tridentine Catholicism. This means that the clergy accepted the classicist style and language, but rejected any changes in models of the natural and social worlds. As a result of the availability of source material, this approach is most apparent in the Diocese of Płock. The clergy accepted only those aspects of the reform which were in line with the practical needs of preaching to the folk, and rejected any intellectually derived ideas. Although they bought and read untraditional books by Kasper Balsam, their own sermons and declarations represented a different worldview. Whereas the bishop of Płock and his collaborators advocated the equality of the different social estates in dignity, mercifulness of God, natural causality, and the value of reason, clergy preached about the differences between the estates in their duties and responsibilities, in the justice and mercifulness of God, in supernatural causality, as well as in the dangers of reasoning. What was similar about bishop and clergy was the conviction that morality was more important than dogma, however, the parsons also underlined the necessity for participation in sacraments. 
Apart from these basic agreements in style and moralizing, the differences are quite striking. However, it is important to question their meaning and consequences. From the anachronistic perspective of contemporary liberal philosophy, the rejection of more enlightened ideas can be interpreted as at least traditionalism and even as obscurantism. In the end, modern ideas of equality, reason, and citizenship were scarcely preached despite bishopric recommendation. However, from the more historic and emic perspective of values jointly believed by bishops and parish clergy, the interpretation would be different. Parsons and vicars adopted the ideas that were not too much in opposition to the predominant views of their faithful, and they also adopted the methodology that helped them improve communication with the folk. Thus, they not only avoided inducing a questioning of the faith, but they also strengthened their relationship with listeners. In a more general perspective, the introduction of the bishops' ideas may have caused a faster division between elite and popular culture [BURKE 2009]. Refuting it may have slowed it down.

\section{Bibliography}

\section{Abbreviated Names of Libraries, Archives, and Depositories}

VUB

Vilniaus Universiteto Biblioteka, Retu spaudiniu skaitykla = Vilnius University Library, Rare Book Reading Room

LVIA

Lietuvos valstybes istorijos archyvas = Lithuanian State Historical Archives

ADPє

Archiwum Diecezjalne w Płocku = Archives of Diocese of Płock

APL

Archiwum Państwowe $w$ Lublinie $=$ State Archives in Lublin

AAL

Archiwum Archidiecezjalne $w$ Lublinie $=$ Archives of Archdiocese of Lublin

BJ

Biblioteka Jagiellońska = Jagiellonian Library in Kraków

Manuscripts

AV 288

ADPł, AV 288, Protokół wizytacji dekanatu Płock, r. 1774.

AV 307

ADPł, AV 307, Protokoły wizytacji dekanatów: Ostrołęka, Ostrów, Wąsocz, Wizna, Wyszków, r. 1774.

F.694. 1.3381

LVIA, F.694.1. 3381 - księga z wieloma niepowiązanymi wizytacjami.

F.694.1.3417

LVIA, F.694.1. b. 3417 - inwentarze parafii Bobrujski, z różnych lat w tym z r. 1796. 


\section{F.694.1.3437}

LVIA, F.694, apr.1, b. 3437 - inwentarz parafii Kossów, r. 1765.

F.694.1.3440

LVIA, F.694, apr.1, b. 3440 - inwentarz parafii Iszkołdź, r. 1766.

F.694.1.3459

LVIA, F.694, apr.1, b. 3459 - księga z różnymi dokumentami w tym z inwentarzem parafii Darewo, r. 1778.

F.694.1.3461

LVIA, F.694, apr.1, b. 3461 - inwentarz parafii Duniłowicze, r. 1774.

F.694.1.3477

LVIA, F.694, apr.1, b. 3477 - inwentarz parafii Duniłowicze, r. 1781.

F.694.1.3478

LVIA, F.694, apr.1, b. 3478 - inwentarz parafii Soleczniki Wielkie r. 1781.

F.694.1.3485

LVIA, F.694, apr.1, b. 3485 - protokół wizytacji parafii Niemenczyn, r. 1782.

F.694.1.3487

LVIA, F.694, apr.1, b. 3487 - protokół wizytacji dekanatu Połock, r. 1782.

F.694.1.3489

LVIA, F.694, apr.1, b. 3489 - protokół wizytacji parafii pod wezwaniem św. Piotra i św. Pawła na Antokolu k. Wilna, r. 1782.

F.694.1.3492

LVIA, F.694, apr.1, b. 3492 - protokół wizytacji dekanatu Raduń, r.1782.

F.694.1.3494

LVIA, F.694, apr.1, b. 3494 - inwentarz parafii Nowe Troki.

F.694.1.3499

LVIA, F.694, apr.1, b. 3499 - protokół wizytacji parafii Petryków, r. 1783.

F.694.1.3500

LVIA, F.694, apr.1, b. 3500 - protokół wizytacji parafii Wołma, r. 1783.

F.694.1.3506

LVIA, F.694, apr.1, b. 3506 - protokół wizytacji parafii Wilno Zarzecze, r. 1784.

F.694.1.3512

LVIA, F.694, apr.1, 3512 - opis parafii pod wezwaniem św. Kazimierza w Wilnie, r. 1785.

F.694.1.3517

LVIA, F.694, apr.1, b. 3517 - fragment całej wizytacji dekanatu Świr, r. 1786 dotyczący parafii Świranki.

F.694.1.3562

LVIA, F.694, apr.1, b. 3562 - protokół wizytacji dekanatu Oszmiana, r. 1798.

F57-B53-175

VUB, F57-B53-175 - inwentarz parafii Wielka Brzostowica, r. 1782.

F57-B53-271

VUB, F57-B53-271 - protokół wizytacji dziekańskiej parafii Wołpa, r. 1782.

F57-B53-308

VUB, F57-B53-308 - protokół wizytacji dziekańskiej parafii Hoża, r. 1783.

F57-B53-460

VUB, F57-B53-460 - inwentarz parafii Zelwa, r. 1783. 


\section{F57-B53-582}

VUB, F57-B53-582 - inwentarz parafii Korkożyszki, r. 1782.

\section{F57-B53-858}

VUB, F57-B53-858 - inwentarz parafii Olkienniki, r. 1765.

F57-B53-947

VUB, F57-B53-947 - protokół wizytacji dziekańskiej parafii Repla, r. 1782.

\section{F57-B53-990}

VUB, F57-B53-990 - protokół wizytacji dziekańskiej parafii Rudomin, r. 1783.

\section{F57-B53-1226}

VUB, F57-B53-1226 - protokół wizytacji dziekańskiej dekanatu Kupiszki, r. 1796.

Rep 60A, 161

AAL, Rep 60A, 161 - protokół wizytacji generalnej diecezji chełmskiej, r. 1763-1764.

Rep 60A, 163

AAL, Rep 60A, 163 - księga zawierająca różne typy dokumentów w tym protokoły wizytacji biskupich rzymskokatolickiej diecezji chełmskiej.

Rep 60A, 164

AAL, Rep 60A, 164 - księga zawierająca różnorodne typy dokumentów w tym protokoły wizytacji biskupich rzymskokatolickiej diecezji chełmskiej.

Rep 60A, 178

AAL, Rep 60A, 178 - wizytacja dekanatów Krasnystaw, Luboml i Chełm, r. 1793-1795.

$35 / 95 / 0 / 5 / 114$

APL, 35/95/0/5/114 - Akta wizytacii i inwentarze cerkwi w dekanatach: chełmskim, dubienieckim, horodelskim, hrubieszowskim, lubelskim, lubomelskim, międzyrzeckim, ratneńskim, szczebrzeskim, tarnogrodzkim i włodawskim. . ., r. 1767-1812.

$35 / 95 / 0 / 5 / 119$

APL, 35/95/0/5/119 - Akta wizyty generalnej dekanatów Lubelskiego i Krasnostawskiego i Chełmskiego..., r. 1774-1774.

$35 / 95 / 0 / 5 / 120$

APL, 35/95/0/5/120 - Wizyta dekanatu Bełskiego..., r. 1774-1775.

$35 / 95 / 0 / 5 / 122$

APL, 35/95/0/5/122 - Wizytacje dziekańskie i inwentarze cerkwi w dekanatach:

strzemieleckim, włodawskim, tyszowieckim, szczebrzeskim. .., r. 1774-1785.

$35 / 95 / 0 / 5 / 124$

APL, 35/95/0/5/124 - Wizyty Generalne Dekanatów Chełmskiego, Sczebrzeskiego y

Zamoyskiego..., r. 1778-1779.

$35 / 95 / 0 / 5 / 127$

APL, 35/95/0/5/127 - Wizyta Generalna dekanatów Horodelskiego [tyszowieckiego, lubelskiego, szczebrzeskiego i zamojskiego]. . ., r. 1779-1780 i 1782-1782.

$35 / 95 / 0 / 5 / 133$

APL, 35/95/0/5/133 - Wizyta generalna dekanatu Ratneńskiego i Kaszogrodzkiego...,

r. $1789-1789$.

$35 / 95 / 0 / 5 / 134$

APL, 35/95/0/5/134 - Akta dawne Konsystorza Chełmskiego i Brzeskiego zawierające wizyty i inwentarze. .., r. 1790-1793. 
$35 / 95 / 0 / 5 / 135$

APL, 35/95/0/5/135 - Wizyta jeneralna dekanatów Krasnostawskiego i Lubelskiego..., r. $1792-1793$.

$35 / 95 / 0 / 5 / 136$

APL, 35/95/0/5/136 - Wizyta jeneralna dekanatu Lubomlskiego. .. , r. 1793.

\section{Editions}

MDDZP, 1-15

GrzY воwsкi M., ed., Materiały do dziejów ziemi płockiej. Z archiwaliów diecezjalnych płockich XVIII wieku, 1-15, Płock, 1982-1998.

LiKOWSKI 1902

Liкowsкi E., ed., Synody Dyecezyi Chetmskiej Obrządku Wschodniego, Poznań, 1902.

FHL, 6

“Kauno dekanato vizitacija 1782," in: J. VytautAs, ed., Fontes Historiae Lituaniae, 6, Vilnius, 2001.

FHL, 7

“Breslaujos dekanato vizitacija 1784," in: R. Firkovicius, ed., Fontes Historiae Lituaniae, 7 , Vilnius, 2008.

FHL, 8

"Ukmerges dekanato vizitacija 1784," in: S. Jegelevicius, ed., Fontes Historiae Lituaniae, 8 , Vilnius, 2009.

FHL, 9

"Pabaisko dekanato vizitacija 1782-1784," in: A. BALIulis, ed., Fontes Historiae Lituaniae, 9, Vilnius, 2010.

\section{Old prints}

\section{BALSAM 1761}

BAlsam K., Kazania na niedziele catego roku. . ., 1, Poznań, 1761.

\section{KAPŁAN SŁUGA BOŻY 1793}

Kaptan stuga boży y pasterz dusz czyli list xiędza plebana do xiędza brata swego zamykaiacy w krótkim zebraniu obowiązki kapłańskie i pasterza dusz, Wilno, 1793.

\section{MASSALSKI 1771}

MASSALSKi I. J., Sposoby proste y tatwe podane od doktorów dla mieszkajacych po wsiach na ustrzerzenie się morowey zarazy, lub ratowanie, pod czas oney. . ., Wilno, 1771 (VUB, IV 31066). 1776

MASSALSKi I. J., Instrukcye na jubileusz dla xx. plebanów, Wilno, 1776 (VUB, IV 24698). 1787

MASSALSKI I., Ignacy Jakob Massalski z bożey y stolicy apostolskiey taski biskup wileński. Całemu duchowieństwu dyecezyi naszey zdrowie y pasterskie błogosławieńśtwo. Nieuradzay lat przeszłych gdy po mimo zapasy bacznych na przysztość gospodarzów dało się uczuć. .., Wilno, 1787 (VUB IV 24705).

KAZANIA NIEKTÓRE 1785

Kazania niektóre księży diecezji ptockiej z podanych co rocznie dwiema ratami w waju i w październiku do kancelarji zadwornej biskupiej 1782. Teraz z tejże kancelarji wydane i do druku podane, 1785.

\section{PONIATOWSKI 1785}

Poniatowski M., Rozrzadzenia y pisma pasterskie za rządów J. O. Xięcia JMCI Michała Jerzego Poniatowskiego Biskupa Ptockiego do diecezyi ptockiey wydane dla wygody teyże Dyecezyi zebrane $i$ do Druku podane, 1-4, Warszawa, 1785. 


\section{RYDZEWSKI 1768A}

Rydzewski W., Kazania Przygodne..., Wilno, 1768.

RYDZEWSKI 1768B

RydzeWsKi W., Kazania Świąteczne. .., Wilno, 1768.

\section{SKARSZEWSKI 1792}

SKARSZEWSKI W., Rozporządzenie pasterskie na dyecezya hetmska lubelska roku 1792, Warszawa, 1792.

WAŻYŃSKI 1792

Ważyński P. S. Katechizm albo krótkie zebranie nauki chrześciańskiey, dla pożytku dusz ludzkich spisane, do druku podane i dna dwie klassy podzielone, Poczajów, 1792.

WujKOWSKi 1733

Wujкошsкі J. S., Chleb duchowny, wszystkim chrześcianom na positek $w$ drodze do nieba idacym wystawiony. Albo raczey, katechizm na świat polski wychodzacy. . ., Kalisz, 1733.

\section{WYsOcKI 1760}

Wysocki S., Adwent z postem. Kazaniami o sądzie bożym, o męce pańskiey, o pokucie, o umartwianiu pięciu ciała zmystów, y inszych prawdach wiary chrześciańskiey, ku większey chwale boskiey, y pożytkom dusz ludzkich po różnych katedrach, z regestrem kaznodzieyskim na wszystkiego catego roku niedziele, Warszawa, 1760.

\section{8}

Wysocki S., Nauki, homilie i materie kazań. .., 3, Warszawa, 1768.

\section{References}

BĄK 2002

BĄK J., Wady ganione i cnoty zalecane w spuściźnie kaznodziejskiej Samuela Wysockiego (17061771), Kalisz, 2002.

BOBRYK 2005

Bовкук W., Duchowieństwo unickiej diecezji chetmskiej w XVIII wieku, Lublin, 2005.

BRZOZOWSKI 1975

Brzozowski M., “Teoria kaznodziejstwa (Wiek XVI-XVIII),” in: M. RechowICZ, red., Dzieje teologii katolickiej w Polsce, 2: Od Odrodzenia do Oświecenia, 1: Teologia humanistyczna, Lublin, 1975, 363-427.

BURKE 2009

Burke P., Kultura ludowa we wczesnonowożytnej Europie, Warszawa, 2009.

BUTTERWICK 2005

Butterwick R., "What Is Enlightenment [Oświecenie]? Some Polish Answers, 1765-1820," Central Europe, 3/1, 2005, 19-37. 2008

Butterwick R., "Between Anti-Enlightenment and Enlightened Catholicism: Provincial Preachers in Late Eighteenth-century Poland-Lithuania," in: R. Butterwick, S. DAVIES, G. SÁnchez Espinosa, eds., Peripheries of the Enlightenment (= Studies on Voltaire and the Eighteenth Century, 2008, 1), Oxford, 2008, 201-228.

2012

Butterwick R., Polska rewolucja a Kościót katolicki 1788-1792, Kraków, 2012. 2014

BUtTERWick R., “Między oświeceniem a katolicyzmem, Czyli o katolickim oświeceniu i oświeconym katolicyzmie,” Wiek Oświecenia, 30, 2014, 11-55.

DĘBIŃSKI 1914

DĘBIŃSKI K., Chetmska rzymsko-katolicka diecezja obrzq̨dku łacińskiego, Lublin, 1914. 
GIL 2005

GIL A., Chetmska diecezja unicka 1596-1810 (= Studia i materiały do dziejów chrześcijaństwa wschodniego w Rzeczypospolitej, 1), Lublin, 2005.

GRZEBIEŃ 1981

GrzebieŃ L. "Kasper Balsam,” in: Stownik Polskich Teologów Katolickich, Warszawa, 1981, 93-94.

GRZYBOWSKI 1973

GrZybowsкi M., "Reforma studiów seminaryjnych w diecezji płockiej biskupa Michała Jerzego Poniatowskiego (1773-1785),” Studia Ptockie, 1, 1973, 175-193.

1983

Grzybowski M., Kościelna działalność Michała Jerzego Poniatowskiego biskupa płockiego 17731785, Warszawa, 1983.

IMAŃSKA 2000

IMAŃSKA I., Drukjako wielofunkcyjny środek przekazu w czasach saskich, Toruń, 2000.

KASABUŁA 1996

KASABUŁA T., "Seminarium diecezjalne wileńskie w okresie rządów biskupa Ignacego

Massalskiego,” Roczniki Teologiczne Katolickiego Uniwersytetu Lubelskiego, 46/4, 1996, 129-144. 1998

KasabuŁa T., Ignacy Massalski biskup wileński, Lublin, 1998.

KUMOR-MIELNIK 2010

KumOR-Mielnik J., "Organizacja terytorialna diecezji chełmskiej i lubelskiej do 1805," Archiwa, Biblioteki i Muzea Kościelne, 94, 2010, 61-77.

\section{ŁAPIŃSKI 1985}

ŁAPIŃSKI J., "Porfiriusz Skarbek Ważyński jako zakonnik i hierarcha unicki," Prawo

Kanoniczne, 28/3-4, 1985, 269-74.

LITAK 1962

LiTAK S., "Akta wizytacyjne parafii z XVI-XVIII w. jako źródło historyczne," Zeszyty Naukowe Katolickiego Uniwersytetu Lubelskiego, 5/3, 1962, 41-58.

PANUŚ 2001

PANUŚ K., Zarys historii kaznodziejstwa w Kościele katolickim, 2: Kaznodziejstwo w Polsce, Kraków, 2001.

PAZERA 2000

Pazera W., Polskie Kaznodziejstwo epoki oświecenia, Częstochowa, 2000.

Pelczar 1886

Pelczar J. B., Zarys dziejów kaznodziejstwa w Kościele katolickim, 1-2, Kraków, 1886.

RUDNICKA 1972

RUDNICKA J., "Ruch księgarski w Warszawie za Stanisława Augusta (1764-1795)," Warszawa XVIII Wieku, 1, Warszawa, 1972, 229-258.

ŚLUSARSKA 1998

ŚLUSARSKA M., "Oświeceniowe modele biskupa, plebana i parafii. Kontynuacja czy zmiana tradycji?” in: Dwór - Plebania - Rodzina chtopska. Szkice z dziejów wsi polskiej XVII i XVIII wieku, Warszawa, 1998, 37-53.

2010

ŚLUSARSKA M., "Ku odnowie życia religijno-moralnego wiernych i poprawie ich obyczajów. Duchowieństwo diecezji wileńskiej w okresie pontyfikatu biskupa Ignacego Jakuba Massalskiego (1762-1794) a oświeceniowa reforma katolicka," Senoji Lietuvos Literatūra, 33, 2010, 171-211. 


\section{SYGOWSKI 2000}

SYGOWSKI P., "Unicka diecezja chełmska w protokołach wizytacyjnych biskupa Maksymiliana Ryłły z lat 1759-1762," in: Miejsce i rola kościoła greckokatolickiego w Kościele powszechnym, 5, Przemyśl, 2000, 233-285.

SZADY 2008

SzADY J., Księgozbiory parafialne w prepozyturze wiślickiej w drugiej połowie XVIII wieku, Lublin, 2008.

SZCZUROWSKI 2004

SzCzURowsKi R., "Jubileuszowe kazania księży Michała Karpowicza (1744-1803) i Wilhelma Kalińskiego (1747-1789) w zmiennych ocenach badaczy," Folia Historica Cracoviensia, 10, 2004, 347-60.

2011

SzCZUROWSKi R., "Pastoralny i literacki wzorzec kapłana doby oświecenia," in:

R. SzCZURowsKi, E. E. WróBeL, red., Historia bliższa ludziom. Prace ofiarowane księdzu profesorowi Janowi Kracikowi w 70. rocznicę urodzin, Kraków, 2011, 333-46. 2014

SzczURowski R., Zaradzić potrzebom doczesnym i wiecznym. Idee oświecenia w Kościele katolickim w Polsce (do 1795 r.), Kraków, 2014.

WiśLICZ 2005

WiśLICZ T., "Jak nauczyć analfabetę? Metodologiczne problemy duszpasterstwa katolickiego w Rzeczpospolitej XVIII wieku," in: S. ACHREMCZYк, red., Między barokiem a oświeceniem. Edukacja, wyksztatcenie, wiedza, Olsztyn, 2005, 161-176.

\section{WITECKI 2017}

WiтECKI S., "Oświeceniowy kanon lektur i jego recepcja wśród płockiego duchowieństwa parafialnego w czasach biskupa Michała Jerzego Poniatowskiego," Zeszyty Naukowe Uniwersytetu Jagiellońskiego. Prace Historyczne, 144/3, 515-538.

N.D.

Witecki S., "Oświecony katolicyzm trydencki. Księgozbiory duchowieństwa parafialnego diecezji płockiej w okresie pontyfikatu bp Michała Jerzego Poniatowskiego,” Wiek Oświecenia (in print).

\section{WOLAŃSKI 2012}

WOLAŃŚKI F., Kaznodziejstwo bernardyńskie w staropolskim systemie komunikacji społecznej schytku epoki saskiej. Studium ksztattowania wyobrażeń i postaw, Toruń, 2012.

WYCZAWSKI 1953

Wyczawski H. E., "Biblioteki parafialne w diecezji krakowskiej u schyłku XVI wieku," Polonia Sacra, 6-7, 1953.

ZAKRZEWSKI 1986

ZAKRZEWSKI A., Idee oświecenia w kazaniach polskich, Częstochowa, 1986.

\section{ZIELIŃSKA 1977}

Zielińska Z., "Michał Jerzy Poniatowski h. Ciołek," in: Polski Stownik Biograficzny (http:// www.ipsb.nina.gov.pl/index.php/a/michal-jerzy-poniatowski-h-ciolek; last accessed on 18.12.2017).

\section{ZWIĄZEK 1977}

ZWIĄZEK J., Katolickie poglady polityczno-społeczne w Polsce na przełomie XVI i XVII wieku w świetle kazań (= Studia Kościelno-Historyczne, 2), Lublin, 1977.

$1997-1998$

ZwiĄZEK J., “Kazania jako źródło historyczne,” in: Folia historica cracoviensia, 4-5, 1997-1998. 
Acknowledgements

Diamond Grant program of the Polish Ministry of Science and Higher Education (2012-2015). Project No. DI2012018742.

\section{mgr Stanisław Witecki}

Uniwersytet Jagielloński w Krakowie, Instytut Historii, doktorant w Zakładzie Antropologii Historycznej

Gołębia 13

31-007 Kraków

Polska/Poland

stanislaw.witecki@gmail.com 